\title{
Why not nursing? Perceptions of the nursing job by young people of high schools - preliminary study
}

Dlaczego nie pielęgniarstwo? Postrzeganie zawodu pielęgniarki przez młodzież szkół licealnych doniesienia wstępne

\section{Anna Leńczuk-Gruba, Anna Idzik, Beata Dziedzic}

Zakład Rozwoju Pielęgniarstwa, Nauk Społecznych i Medycznych, Wydział Nauki o Zdrowiu, Warszawski Uniwersytet Medyczny/ Department of Nursing Development, Faculty of Health Sciences, Medical University of Warsaw

ORCID: Anna Idzik: 0000-0001-9112-1956

Beata Dziedzic: 0000-0003-4099-6597

\section{CORRESPONDING AUTHOR/AUTOR DO KORESPONDENCJ:}

Anna Leńczuk-Gruba

Department of Nursing Development, Faculty of Health Sciences Zakład Rozwoju Pielęgniarstwa, Nauk Społecznych i Medycznych ul. Erazma Ciołka 27, 01-445 Warszawa e-mail: anna.l-g@wp.pl

\section{DONIESIENIA WSTEPNE}

Cel pracy. W pracy podjęto próbę analizy zainteresowania uczniów szkół licealnych kształceniem w zawodzie pielęgniarki.

Materiał i metody. Badaniem objęto grupę 307 uczniów klas maturalnych w okresie od stycznia do marca 2018. Do badań wykorzystano autorski kwestionariusz ankiety oraz standaryzowaną Listę Wartości Osobistych (LW0) według Z. Juczyńskiego.

Wyniki. Decyzję kształcenia na kierunku pielęgniarskim potwierdziły tylko 2 osoby. 13\% uczniów rozważało ewentualny wybór pielęgniarstwa jako kierunku rezerwowego. Za czynniki zniechęcające do kształcenia w zawodzie młodzież wskazała niskie wynagrodzenie, specyfikę pracy związaną z „,brudną i trudną pracą", małe uznanie dla zawodu w społeczeństwie. Respondenci postrzegający zawód pielęgniarki jako prestiżowy, częściej deklarowali zainteresowanie kształceniem na kierunku pielęgniarskim $(\mathrm{p}<0,001)$.

Wnioski. Zainteresowanie zawodem pielęgniarki/pielęgniarza jest bardzo małe. Konieczne jest podjęcie działań w zakresie promocji zawodu, które przełożą się na postrzeganie przez młodzież zawodu pielęgniarskiego jako atrakcyjnego.

Słowa kluczowe: wybór zawodu, wartości osobiste, młodzież, pielęgniarstwo

Aim. The work aimed at evaluating the interest in learning nursing profession among students of high schools.

Material and methods. The research comprised a group of 307 students from high schools. The research has been conducted between January - April 2018. The methods used were the diagnostic survey method. The self-construction questionnaire and the questionnaire - List of Personal Values by Z. Juczyński were also used.

Results. The willingness to start learning the profession of a field nurse has been declared only by 2 persons. $13 \%$ of students considered nursing studies as a substitute field of study. The factors that discourage the young to learn the profession include low remuneration, specificity of the profession that implies "dirty and difficult work", low social esteem for the profession, The students, who more often identify the profession of a nurse as prestigious, declared interest in learning that profession $(p<0,001)$.

Conclusions. Interest in the profession of a field nurse is very low. It is necessary to start promoting the profession in order to make the young perceive it as more attractive.

Key words: $\quad$ choice of profession, personal values, young people, nursing 


\section{INTRODUCTION}

For a long time in the world and in most European countries including Poland, there has been a deficit in the nursing staff. The main reasons for this phenomenon are nurses leaving the profession early, insufficient inflow of young nursing adepts to work, as well as very low interest of young people in education in the nursing profession $[1,2]$. Low remuneration, specificity of work and low prestige of the profession are considered the main reasons for the lack of interest in education in the nursing profession [3-6]. In 2017 in Poland, as part of the Strategy for the development of nursing and obstetrics in Poland, actions were planned to implement a nationwide media campaign showing the positive image and diversity of the nurses' work, which aimed at encouraging young people to choose this course of education [7]. To make the activities planned as part of the campaign effective, it is worth referring to the issue of professional and educational aspirations of the modern youth, in whom educators see a change in the direction of thinking in terms of choosing the path of education. Among the criteria conditioning the choice of career path by young people, the economic aspect, the impact of the surrounding environment, the socio-legal system, the need for self-fulfilment as well as hedonistic aspects are currently emphasized [8,9]. Unfortunately, in the Polish literature, there are few publications on the significance of values preferred by the youth in the context of the choice of nursing education.

\section{AIM}

The main aim of this paper was an attempt to analyse the interest in nursing education among high school students, and to learn about factors which influence the lack of interest in the profession of a nurse.

\section{MATERIALS AND METHODS}

The study was conducted from January to March 2018 among senior high school students in the high schools of the mazowieckie and lubelskie voivodships. The research was carried out after obtaining the written consent of the school headmaster. The respondents were informed about the voluntary participation in the study, the purpose of the tests, the confidentiality of the surveys, and how to complete them. The respondents expressed an informed consent to participate in the study. 321 questionnaires were distributed and 307 correctly completed questionnaires were qualified for the final analysis.

Researchers used the diagnostic survey method; the research tool was the original questionnaire and the standardized List of Personal Values by Z. Juczyński. The original survey contained a metric with general questions such as age, sex, class profile, and the place of residence. The second part included questions about interest in nursing education and the perception of the prestige of the profession. The second research tool, i.e. the List of Personal Values, is used to estimate the importance of personal values and symbols of happiness that are important to the individual. Out of 9 symbols of luck and 10 personal values, the respondents selected the 5 most important ones for themselves, assessing them on a scale from 5 (the most important value/symbol) to 1 (the lowest significance) [10].

A statistical analysis of the obtained data was performed with the IBM SPSS Statistics 22 package. In order to check whether there is a significant relationship between individual variables, the non-parametric chi-square test, the Kruskal Wallis test and V-Kramer were used. A statistically significant level was set to $\mathrm{p}<0.05$.

\section{RESULTS}

The largest number of respondents were women (72.6\%); they were interested in starting nursing education than men $\mathrm{p}<0.001, \mathrm{~V}$ Kramer $=0.29$, Chi-square $=$ $24.81(\mathrm{df}=2)$.

Only two respondents confirmed their willingness to undertake nursing education, 9.5\% considered choosing nursing, and $13.1 \%$ of students considered choosing nursing as a backup (Fig.1).

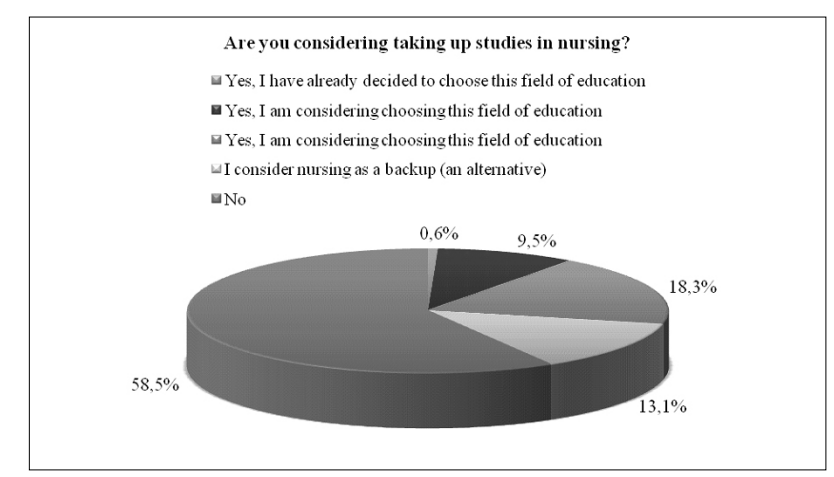

Fig 1. Interest of students in nursing education

Among the reasons for the lack of interest in nursing in a group of 179 respondents, $53.7 \%$ indicated low remuneration, $37.1 \%$ perceived the nurses' work as „dirty” and difficult, and $30.9 \%$ of students emphasized little recognition for the profession in the society (Fig. 2).

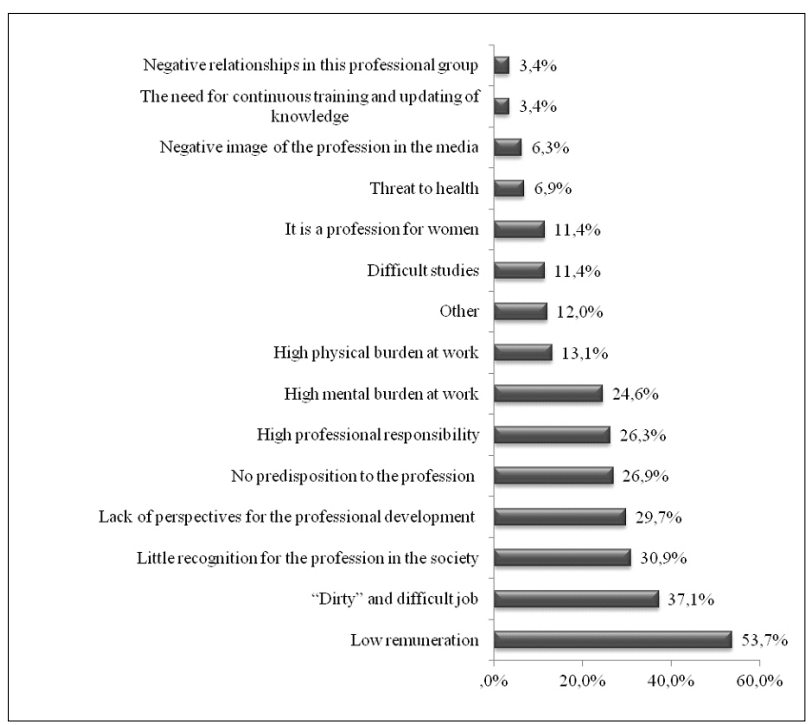

Fig 2. Reasons for the lack of interest of respondents in nursing education $(\mathrm{N}=179)$ 
Anna Leńczuk-Gruba, Anna Idzik, Beata Dziedzic

Tab. 1. The respondents' interest in nursing education and the prestige assessment of the nursing profession

\begin{tabular}{|c|c|c|c|c|c|c|c|}
\hline & & & \multicolumn{4}{|c|}{$\begin{array}{l}\text { At what level do you think the prestige (social respect, } \\
\text { recognition, respect) of the nursing profession is? }\end{array}$} & \multirow{2}{*}{ Total } \\
\hline & & & High & Medium & Low & $\begin{array}{l}\text { This profession } \\
\text { is not prestigious }\end{array}$ & \\
\hline \multirow{6}{*}{$\begin{array}{l}\text { Are you considering taking up } \\
\text { the studies in nursing? }\end{array}$} & \multirow{2}{*}{ Yes, I am thinking about this field of study } & $\mathrm{N}$ & 6 & 46 & 13 & 4 & 69 \\
\hline & & $\%$ & $50.0 \%$ & $27.9 \%$ & $13.8 \%$ & $12.1 \%$ & $22.7 \%$ \\
\hline & \multirow{2}{*}{$\begin{array}{l}\text { I have not made a decision regarding } \\
\text { the choice of education yet }\end{array}$} & $\mathrm{N}$ & 4 & 39 & 9 & 4 & 56 \\
\hline & & $\%$ & $33.3 \%$ & $23.6 \%$ & $9.6 \%$ & $12.1 \%$ & $18.4 \%$ \\
\hline & \multirow{2}{*}{ No } & $\mathrm{N}$ & 2 & 80 & 72 & 25 & 179 \\
\hline & & $\%$ & $16.7 \%$ & $48.5 \%$ & $76.6 \%$ & $75.8 \%$ & $58.9 \%$ \\
\hline \multirow{2}{*}{\multicolumn{2}{|c|}{ Total }} & $\mathrm{N}$ & 12 & 165 & 94 & 33 & 304 \\
\hline & & $\%$ & $100.0 \%$ & $100.0 \%$ & $100.0 \%$ & $100.0 \%$ & $100.0 \%$ \\
\hline \multicolumn{8}{|c|}{$\mathrm{p}<0.001$, Kramer's V $=0.23$, Chi-square $=32.63(\mathrm{df}=6)$} \\
\hline
\end{tabular}

Tab. 2. Respondents' interest in nursing education and the importance of symbols of happiness

\begin{tabular}{|c|c|c|c|c|c|c|c|c|c|c|c|}
\hline \multicolumn{3}{|c|}{ p Kruskal Wallis test } & 0.507 & 0.704 & 0.171 & 0.271 & 0.441 & 0.062 & 0.005 & 0.004 & 0.209 \\
\hline \multirow{12}{*}{$\begin{array}{l}\text { Are you } \\
\text { considering } \\
\text { taking up } \\
\text { studies in } \\
\text { nursing? }\end{array}$} & \multirow{4}{*}{ No } & \begin{tabular}{|l|} 
Standard \\
deviation \\
\end{tabular} & 1.497 & 1.833 & 1.606 & 1.434 & 1.726 & 1.700 & 1.532 & 1.439 & 0.470 \\
\hline & & $\mathrm{N}$ & 179 & 179 & 179 & 179 & 179 & 179 & 179 & 179 & 179 \\
\hline & & Median & 0.00 & 4.00 & 2.00 & 1.00 & 4.00 & 1.00 & 1.00 & 0.00 & 0.00 \\
\hline & & Mean & 0.92 & 3.43 & 2.17 & 1.20 & 3.22 & 1.44 & 1.42 & 1.12 & 0.09 \\
\hline & \multirow{4}{*}{\begin{tabular}{|c|} 
I have not \\
made a \\
decision \\
regarding \\
the choice of \\
education yet
\end{tabular}} & \begin{tabular}{|l|} 
Standard \\
deviation \\
\end{tabular} & 1.483 & 1.767 & 1.486 & 1.616 & 1.798 & 1.600 & 1.498 & 1.822 & 0.549 \\
\hline & & $\mathrm{N}$ & 56 & 56 & 56 & 56 & 56 & 56 & 56 & 56 & 56 \\
\hline & & Median & 0.00 & 4.00 & 2.00 & 1.00 & 3.00 & 0.50 & 0.00 & 1.00 & 0.00 \\
\hline & & Mean & 0.98 & 3.57 & 1.71 & 1.59 & 2.93 & 1.36 & 1.11 & 1.66 & 0.09 \\
\hline & \multirow{4}{*}{$\begin{array}{c}\text { Yes, I am } \\
\text { thinking } \\
\text { about this } \\
\text { field of study }\end{array}$} & \begin{tabular}{|l|} 
Standard \\
deviation
\end{tabular} & 1.484 & 1.736 & 1.455 & 1.677 & 1.496 & 1.744 & 1.298 & 1.325 & 0.000 \\
\hline & & $\mathrm{N}$ & 69 & 69 & 69 & 69 & 69 & 69 & 69 & 69 & 69 \\
\hline & & Median & 0.00 & 4.00 & 2.00 & 1.00 & 4.00 & 2.00 & 0.00 & 0.00 & 0.00 \\
\hline & & Mean & 1.13 & 3.57 & 2.03 & 1.33 & 3.38 & 1.96 & 0.86 & 0.74 & 0.00 \\
\hline \multicolumn{3}{|c|}{ Symbols of happiness } & $\begin{array}{l}\text { Large group } \\
\text { of friends }\end{array}$ & $\begin{array}{c}\text { Happy } \\
\text { family life }\end{array}$ & $\begin{array}{c}\text { Working } \\
\text { in one's } \\
\text { favourite } \\
\text { job }\end{array}$ & $\begin{array}{c}\text { Success in } \\
\text { education/ } \\
\text { professional } \\
\text { career }\end{array}$ & Good health & $\begin{array}{c}\text { Being } \\
\text { needed to } \\
\text { other people }\end{array}$ & $\begin{array}{c}\text { Good } \\
\text { material } \\
\text { conditions }\end{array}$ & $\begin{array}{l}\text { Life full of } \\
\text { journeys and } \\
\text { adventures }\end{array}$ & $\begin{array}{c}\text { Fame, } \\
\text { popularity }\end{array}$ \\
\hline
\end{tabular}

The statistical analysis showed that the students who declared the perception of the nursing profession as prestigious were more interested in undertaking education in this field $\mathrm{p}<0.001$ (Tab.1).

The statistical analysis of the relationship between students' interest in nursing education and the values that determine personal happiness showed that respondents who assessed the value of "good material conditions" and the value of „adventurous life and travel” higher, more often declared the lack of interest in nursing. The variable „being needed by other people” was near the level of significance; it was ranked higher by respondents who were thinking about choosing the field of nursing education (Tab. 2).

The assessment of the relationship between the students' interest in nursing education and the importance of personal values did not show statistically significant differentiation (Tab. 3).

\section{DISCUSSION}

The growing problem of the shortage of medical staff is one of many difficulties that the Polish healthcare system is struggling with. The level of health care expenditure in Poland is one of the lowest in Europe both in nominal terms and with regard to the value of GDP. If the amount of funds for the health care does not change, it will not be possible for health care to function properly in our country [11]. Data from the Report of the Supreme Council of Nurses and Midwives show that in 2016, the employment rate of nurses in Poland was 5.24 per 1,000 inhabitants, which was the lowest result in the European countries, and forecasts for 2030 are dramatic because it is estimated that this indicator will amount to only 3.81 in 2030 [12]. The age structure of nurses in Poland indicates a growing problem of the lack of replacement of generations in these professional groups. One of the reasons for this unfavourable phenomenon is the low interest of young people in the nursing education [7].

In the author's own study, only two people declared their willingness to start nursing education, and only a few 
Why not nursing? Perceptions of the nursing job by young people of high schools - preliminary study

- Tab. 3. Respondents' interest in nursing education and the importance of personal values

\begin{tabular}{|c|c|c|c|c|c|c|c|c|c|c|c|c|}
\hline \multicolumn{3}{|c|}{ p Kruskal Wallis test } & 0.960 & 0.135 & 0.177 & 0.097 & 0.500 & 0.154 & 0.846 & 0.404 & 0.684 & 0.158 \\
\hline \multirow{12}{*}{$\begin{array}{l}\text { Are you } \\
\text { considering } \\
\text { taking up } \\
\text { studies in } \\
\text { nursing? }\end{array}$} & \multirow{4}{*}{ No } & $\begin{array}{l}\text { Standard } \\
\text { deviation } \\
\end{array}$ & 1.666 & 1.851 & 1.454 & 1.672 & 1.529 & 1.589 & 0.977 & 0.796 & 0.609 & 1.079 \\
\hline & & $\mathrm{N}$ & 179 & 179 & 179 & 179 & 179 & 79 & 179 & 179 & 179 & 179 \\
\hline & & Median & 5.00 & 3.00 & 0.00 & 3.00 & 0.00 & 0.00 & 0.00 & 0.00 & 0.00 & 0.00 \\
\hline & & Mean & 3.82 & 2.37 & 1.05 & 2.30 & 1.10 & 1.25 & 0.43 & 0.20 & 0.13 & 0.36 \\
\hline & \multirow{4}{*}{$\begin{array}{c}\text { I have not } \\
\text { made a } \\
\text { decision } \\
\text { regarding } \\
\text { the choice of } \\
\text { education yet }\end{array}$} & $\begin{array}{l}\text { Standard } \\
\text { deviation }\end{array}$ & 1.587 & 1.916 & 1.257 & 1.607 & 1.342 & 1.627 & 1.073 & 0.757 & 0.394 & 0.624 \\
\hline & & $\mathrm{N}$ & 56 & 56 & 56 & 56 & 56 & 56 & 56 & 56 & 56 & 56 \\
\hline & & Median & 5.00 & 3.00 & 0.00 & 3.00 & 0.00 & 0.00 & 0.00 & 0.00 & 0.00 & 0.00 \\
\hline & & Mean & 3.91 & 2.70 & 0.95 & 2.48 & 0.98 & 1.16 & 0.39 & 0.16 & 0.09 & 0.29 \\
\hline & \multirow{4}{*}{$\begin{array}{c}\text { Yes, I am } \\
\text { thinking } \\
\text { about this } \\
\text { field of study }\end{array}$} & $\begin{array}{l}\text { Standard } \\
\text { deviation } \\
\end{array}$ & 1.717 & 1.912 & 1.169 & 1.577 & 1.516 & 1.756 & 1.035 & 0.268 & 0.431 & 0.576 \\
\hline & & $\mathrm{N}$ & 69 & 69 & 69 & 69 & 69 & 69 & 69 & 69 & 69 & 69 \\
\hline & & Median & 5.00 & 4.00 & 0.00 & 2.00 & 0.00 & 1.00 & 0.00 & 0.00 & 0.00 & 0.00 \\
\hline & & Mean & 3.81 & 2.86 & 0.68 & 1.88 & 1.29 & 1.65 & 0.42 & 0.04 & 0.07 & 0.14 \\
\hline \multicolumn{3}{|c|}{ Personal values } & $\begin{array}{l}\text { Love, } \\
\text { friendship }\end{array}$ & $\begin{array}{c}\text { Good } \\
\text { health, } \\
\text { physical } \\
\text { fitness and } \\
\text { mental } \\
\text { abilities }\end{array}$ & $\begin{array}{c}\text { Sense of } \\
\text { humour, } \\
\text { wit }\end{array}$ & $\begin{array}{c}\text { Intelligence } \\
\text { and } \\
\text { brightness }\end{array}$ & $\begin{array}{c}\text { Knowledge, } \\
\text { wisdom }\end{array}$ & $\begin{array}{c}\text { Joy, } \\
\text { satisfaction }\end{array}$ & $\begin{array}{l}\text { Courage, } \\
\text { resoluteness }\end{array}$ & $\begin{array}{l}\text { Kindness, } \\
\text { gentleness }\end{array}$ & $\begin{array}{c}\text { Good } \\
\text { appearance }\end{array}$ & $\begin{array}{c}\text { Wealth, } \\
\text { assets }\end{array}$ \\
\hline
\end{tabular}

respondents considered a potential choice of this field of education. Similar results were obtained by W. Mędrzycka - Dąbrowska et al. in which only $10 \%$ of girls and $5 \%$ of boys (among 383 respondents) considered education in the profession of a nurse [13]. In the research by Franek G. et al., among 100 high school students, the percentage of those interested in the profession was $17 \%$, of which only $9 \%$ declared their willingness to study in the profession [14]. Low interest in nursing studies was also indicated in the research by A. Krzos et al. in which $6.6 \%$ of high school students wanted to study nursing in the future [15]. According to the research results of M. Pierzak in 2016, 27 people out of 105 surveyed high school students were interested in studying nursing [16]. The quoted results should provoke a reflection on the reason for such a low interest in the nursing education. The results of the author's own research confirmed the importance of low remuneration, specificity of work and low recognition for the profession in the society. Similar results were obtained by the authors of other papers on this problem [13-15].

Nowadays, young people perceive the high rank and prestige of the profession mainly in the context of economy, i.e. the attractiveness of remuneration for work - a factor that had a significant impact on the small interest of youth in nursing education, according to the author's own research. Ślusarska B et al. emphasize the importance of recognising personal values as a foundation for shaping professional values in nursing [17]. According to the author's own study, the most appreciated values of young people were love and friendship as well as good health, and physical and mental fitness. Successful family life and good health were considered the most important symbols of happiness. It is worth pointing out that the value of „being needed for other people” was more valued by respondents who considered choosing a nursing profession.
Contemporary nursing creates the basis for further positive changes in terms of competence, prestige and professional satisfaction, and can be an attractive profession for young people, especially because of its noble mission, values and tradition. However, according to

D. Koralewicz et al., nowadays is definitely not enough to encourage Polish youth to work in this profession [18].

\section{CONCLUSIONS}

The interest of young people in training to become a nurse is very small. The lack of interest in the nursing education is primarily determined by the level of remuneration, perception of the specifics of work and the prestige of the profession.

Urgent measures are needed to promote the profession, which will translate into the perception of the nursing profession as attractive by young people. 


\section{Dlaczego nie pielęgniarstwo? Postrzeganie zawodu pielęgniarki przez młodzież szkół licealnych - doniesienia wstępne}

\section{WPROWADZENIE}

Od dłuższego czasu na świecie i w większości krajów europejskich, w tym w Polsce odczuwany jest deficyt personelu pielęgniarskiego. Głównymi przyczynami tego zjawiska jest przedwczesne odejście pielęgniarek $\mathrm{z}$ zawodu, niedostateczny napływ młodych adeptów pielęgniarstwa do pracy, a także bardzo małe zainteresowanie młodzieży kształceniem w zawodzie pielęgniarskim [1,2]. Za główne powody braku zainteresowania kształceniem w zawodzie pielęgniarki wskazuje się niskie zarobki, specyfikę pracy oraz niski prestiż zawodu [3-6]. W Polsce w 2017 roku w ramach Strategii na rzecz rozwoju pielęgniarstwa i położnictwa zaplanowano podjęcie działań mających na celu wdrożenie ogólnopolskiej kampanii w mediach ukazującej pozytywny wizerunek i różnorodność pracy pielęgniarki, która ma na celu zachęcić młodzież do wyboru tego kierunku kształcenia [7]. Aby zaplanowane $w$ ramach kampanii działania były skuteczne, warto odnieść się do zagadnienia aspiracji zawodowych i edukacyjnych współczesnej młodzieży, u której pedagodzy dostrzegają zmianę kierunku myślenia w zakresie wyboru drogi kształcenia. Wśród kryteriów warunkujących wybór przez młodzież ścieżki kariery zawodowej podkreśla się obecnie przede wszystkim aspekt ekonomiczny, wpływ otaczającego środowiska, system społeczno-prawny, potrzebę samorealizacji, a także względy hedonistyczne $[8,9]$. Niestety w piśmiennictwie polskim jest niewiele publikacji analizujacych znaczenia preferowanych przez młodzież wartości w kontekście wyboru kształcenia w zawodzie pielęgniarki.

\section{CEL}

Celem głównym pracy była próba analizy zainteresowania kształceniem na kierunku pielęgniarstwo wśród uczniów szkół licealnych oraz poznanie czynników wpływających na brak zainteresowania zawodem pielęgniarki.

\section{MATERIAŁ I METODY}

Badanie przeprowadzono w okresie od stycznia do marca 2018 roku wśród uczniów klas maturalnych, w szkołach licealnych województwa mazowieckiego i lubelskiego. Badania przeprowadzono po wcześniejszym uzyskaniu pisemnej zgody dyrekcji szkół. Ankietowanych poinformowano o dobrowolności udziału w badaniu, celu przeprowadzanych badań, poufności ankiet, oraz sposobie ich wypełnienia. Respondenci wyrazili świadomą zgodę na udział w badaniu. Rozdano 321 ankiet, a do ostatecznej analizy zakwalifikowano 307 poprawnie wypełnionych kwestionariuszy ankiet.

W badaniach posłużono się metodą sondażu diagnostycznego, narzędzie badawcze stanowił autorski kwestio- nariusz ankiety oraz standaryzowana Lista Wartości Osobistych (LWO) autorstwa Z. Juczyńskego. Ankieta autorska zawierała metryczkę, w której zamieszczono pytania ogólne, takie jak: wiek, płeć, profil klasy, miejsce zamieszkania. Druga część uwzględniała pytania dotyczące zainteresowania kształceniem $\mathrm{w}$ zawodzie pielęgniarki oraz postrzegania prestiżu zawodu. Drugie narzędzie badawcze - Lista Wartości Osobistych (LWO), służy do oszacowania znaczenia wartości osobistych i symboli szczęścia ważnych dla jednostki. Respondenci spośród 9 symboli szczęścia i 10 wartości osobistych dokonywali wyboru 5 najważniejszych dla siebie, przypisując im rangę od 5 (najważniejsza wartość/symbol) do 1 (najniższa wartość) [10].

Analiza statystyczna uzyskanych danych została wykonana przy użyciu pakietu IBM SPSS Statistics 22 . W celu sprawdzenia czy występuje istotna zależność pomiędzy poszczególnymi zmiennymi, zastosowano nieparametryczny test chi - kwadrat, oraz test Kruskala Wallisa i V-Kramera. Za poziom istotny statystycznie przyjęto wartość $\mathrm{p}<0,05$.

\section{WYNIKI BADAŃ}

Największą liczbę respondentów stanowiły kobiety (72,6\%), które w większym stopniu od mężczyzn były zainteresowane podjęciem kształcenia na kierunku pielęgniarstwo $\mathrm{p}<0,001$, V Kramera $=0,29$, Chi-kwadrat $=24,81$ $(\mathrm{df}=2)$. Tylko 2 respondentów potwierdziło chęć podjęcia kształcenia w zawodzie pielęgniarki, 9,5\% zastanawiało się nad wyborem pielęgniarstwa, a 13,1\% uczniów rozważało ewentualny wybór pielęgniarstwa jako kierunku rezerwowego (Ryc.1).

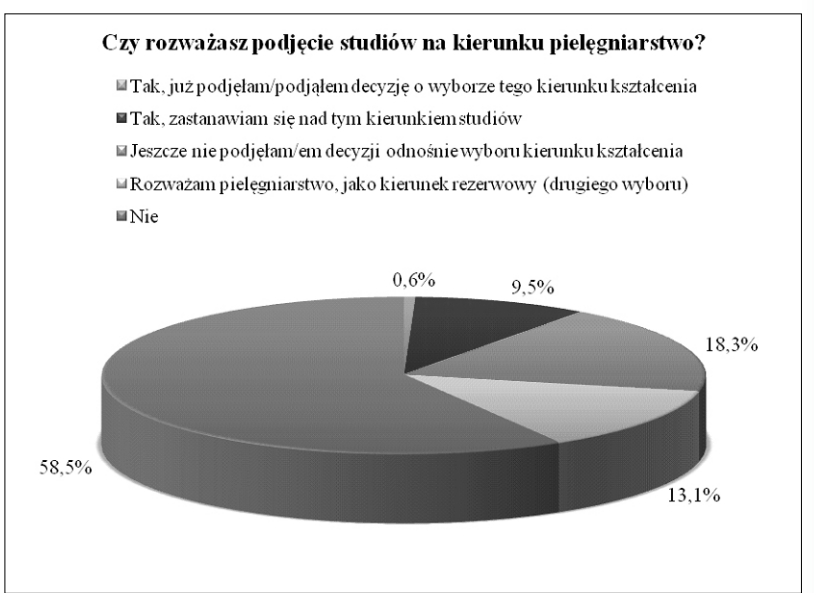

Ryc 1. Zainteresowanie uczniów kształceniem na kierunku pielęgniarstwo

Wśród przyczyn braku zainteresowania pielęgniarstwem w grupie 179 respondentów, 53,7\% wskazało na niskie wynagrodzenie, $37,1 \%$ postrzegało pracę pielęgniarki jako „brudną" i trudną, a 30,9\% uczniów podkreślało małe uznanie dla zawodu w społeczeństwie (Ryc.2). 


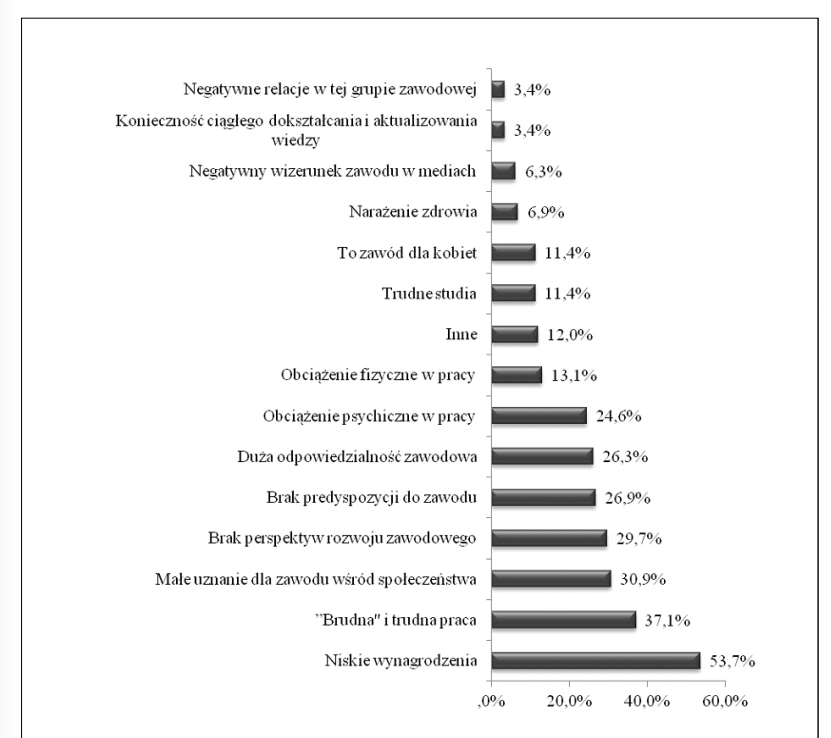

Ryc 2. Przyczyny braku zainteresowania respondentów kształceniem w zawodzie pielęgniarki $(\mathrm{N}=179)$
Analiza statystyczna wykazała, że uczniowie deklarujący postrzeganie zawodu pielęgniarki jako prestiżowego $\mathrm{w}$ większym stopniu byli zainteresowani podjęciem kształcenia na tym kierunku $\mathrm{p}<0,001$ (Tab.1).

Analiza statystyczna związku pomiędzy zainteresowaniem uczniów kształceniem na kierunku pielęgniarstwo a wartościami decydującymi o szczęściu osobistym wykazała, że respondenci, którzy wyżej cenili wartość „, dobre warunki materialne” oraz wartość „życie pełne przygód, podróży" częściej deklarowali brak zainteresowania pielęgniarstwem. Blisko poziomu istotności była zmienna „bycie potrzebnym dla innych ludzi”, którą wyżej rangowali respondenci, którzy zastanawiali się nad wyborem kierunku pielęgniarstwa (Tab.2).

Ocena związku pomiędzy zainteresowaniem uczniów kształceniem na kierunku pielęgniarstwo a znaczeniem wartości osobistych nie wykazała zróżnicowania istotnego statystycznie (Tab. 3).

Tab. 1.Zainteresowanie respondentów kształceniem na kierunku pielęgniarskim a ocena prestiżu zawodu pielęgniarki

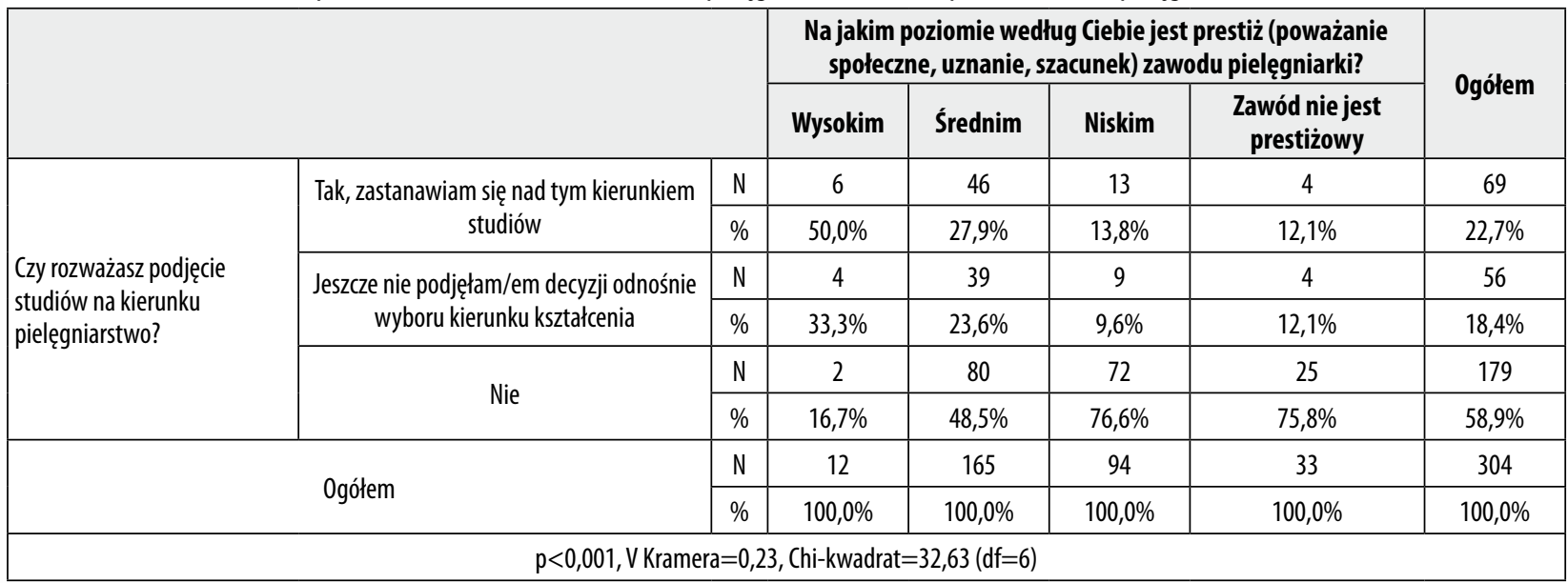

Tab. 2. Zainteresowanie respondentów kształceniem na kierunku pielęgniarstwo a znaczenie symboli szczęścia

\begin{tabular}{|c|c|c|c|c|c|c|c|c|c|c|c|}
\hline \multicolumn{3}{|c|}{ p Kruskal Wallis test } & 0,507 & 0,704 & 0,171 & 0,271 & 0,441 & 0,062 & 0,005 & 0,004 & 0,209 \\
\hline \multirow{12}{*}{\begin{tabular}{|l|} 
Czy rozważasz \\
podjęcie studiów \\
na kierunku \\
pielęgniarstwo?
\end{tabular}} & \multirow{4}{*}{$\mathrm{Nie}$} & \begin{tabular}{|c}
$\begin{array}{c}\text { Odchylenie } \\
\text { standardowe }\end{array}$ \\
\end{tabular} & 1,497 & 1,833 & 1,606 & 1,434 & 1,726 & 1,700 & 1,532 & 1,439 & 0,470 \\
\hline & & N & 179 & 179 & 179 & 179 & 179 & 179 & 179 & 179 & 179 \\
\hline & & Mediana & 0,00 & 4,00 & 2,00 & 1,00 & 4,00 & 1,00 & 1,00 & 0,00 & 0,00 \\
\hline & & Średnia & 0,92 & 3,43 & 2,17 & 1,20 & 3,22 & 1,44 & 1,42 & 1,12 & 0,09 \\
\hline & \multirow{4}{*}{$\begin{array}{c}\text { Jeszcze nie } \\
\text { podjęłam/em } \\
\text { decyzji odnośnie } \\
\text { wyboru kierunku } \\
\text { kształcenia }\end{array}$} & $\begin{array}{c}\text { Odchylenie } \\
\text { standardowe }\end{array}$ & 1,483 & 1,767 & 1,486 & 1,616 & 1,798 & 1,600 & 1,498 & 1,822 & 0,549 \\
\hline & & $\mathrm{N}$ & 56 & 56 & 56 & 56 & 56 & 56 & 56 & 56 & 56 \\
\hline & & Mediana & 0,00 & 4,00 & 2,00 & 1,00 & 3,00 & 0,50 & 0,00 & 1,00 & 0,00 \\
\hline & & Średnia & 0,98 & 3,57 & 1,71 & 1,59 & 2,93 & 1,36 & 1,11 & 1,66 & 0,09 \\
\hline & \multirow{4}{*}{$\begin{array}{l}\text { Tak, zastanawiam } \\
\text { się nad tym } \\
\text { kierunkiem } \\
\text { studiów }\end{array}$} & \begin{tabular}{|c} 
Odchylenie \\
standardowe
\end{tabular} & 1,484 & 1,736 & 1,455 & 1,677 & 1,496 & 1,744 & 1,298 & 1,325 & 0,000 \\
\hline & & $\mathrm{N}$ & 69 & 69 & 69 & 69 & 69 & 69 & 69 & 69 & 69 \\
\hline & & Mediana & 0,00 & 4,00 & 2,00 & 1,00 & 4,00 & 2,00 & 0,00 & 0,00 & 0,00 \\
\hline & & Średnia & 1,13 & 3,57 & 2,03 & 1,33 & 3,38 & 1,96 & 0,86 & 0,74 & 0,00 \\
\hline \multicolumn{3}{|l|}{ Symbole szczęścia } & $\begin{array}{c}\text { Duży } \\
\text { krąg } \\
\text { przyjaciół }\end{array}$ & $\begin{array}{c}\text { Udane } \\
\text { życie } \\
\text { rodzinne }\end{array}$ & $\begin{array}{c}\text { Wykonywanie } \\
\text { ulubionej } \\
\text { pracy, zawodu }\end{array}$ & $\begin{array}{c}\text { Sukcesy } \\
\text { w nauce, } \\
\text { pracy }\end{array}$ & $\begin{array}{l}\text { Dobre } \\
\text { zdrowie }\end{array}$ & $\begin{array}{c}\text { Bycie } \\
\text { potrzebnym } \\
\text { dla innych } \\
\text { ludzi }\end{array}$ & $\begin{array}{c}\text { Dobre } \\
\text { warunki } \\
\text { materialne }\end{array}$ & $\begin{array}{c}\text { Życie pełne } \\
\text { przygód, } \\
\text { podróży }\end{array}$ & $\begin{array}{c}\text { Sława, } \\
\text { popularność }\end{array}$ \\
\hline
\end{tabular}


Anna Leńczuk-Gruba, Anna Idzik, Beata Dziedzic

Tab. 3. Zainteresowanie respondentów kształceniem na kierunku pielęgniarstwo a znaczenie wartości osobistych

\begin{tabular}{|c|c|c|c|c|c|c|c|c|c|c|c|c|}
\hline \multicolumn{3}{|c|}{ p Kruskal Wallis test } & 0,960 & 0,135 & 0,177 & 0,097 & 0,500 & 0,154 & 0,846 & 0,404 & 0,684 & 0,158 \\
\hline \multirow{12}{*}{\begin{tabular}{|l|} 
Czy rozważasz \\
podjęcie \\
studiów na \\
kierunku \\
pielęgniarstwo?
\end{tabular}} & \multirow{4}{*}{ Nie } & \begin{tabular}{|c|} 
Odchylenie \\
standardowe \\
\end{tabular} & 1,666 & 1,851 & 1,454 & 1,672 & 1,529 & 1,589 & 0,977 & 0,796 & 0,609 & 1,079 \\
\hline & & $\mathrm{N}$ & 179 & 179 & 179 & 179 & 179 & 79 & 179 & 179 & 179 & 179 \\
\hline & & Mediana & 5,00 & 3,00 & 0,00 & 3,00 & 0,00 & 0,00 & 0,00 & 0,00 & 0,00 & 0,00 \\
\hline & & Średnia & 3,82 & 2,37 & 1,05 & 2,30 & 1,10 & 1,25 & 0,43 & 0,20 & 0,13 & 0,36 \\
\hline & \multirow{4}{*}{\begin{tabular}{|c|} 
Jeszcze nie \\
podjęłam/ \\
em decyzji \\
odnośnie \\
wyboru \\
kierunku \\
kształcenia \\
\end{tabular}} & \begin{tabular}{|c|} 
Odchylenie \\
standardowe
\end{tabular} & 1,587 & 1,916 & 1,257 & 1,607 & 1,342 & 1,627 & 1,073 & 0,757 & 0,394 & 0,624 \\
\hline & & $\mathrm{N}$ & 56 & 56 & 56 & 56 & 56 & 56 & 56 & 56 & 56 & 56 \\
\hline & & Mediana & 5,00 & 3,00 & 0,00 & 3,00 & 0,00 & 0,00 & 0,00 & 0,00 & 0,00 & 0,00 \\
\hline & & Średnia & 3,91 & 2,70 & 0,95 & 2,48 & 0,98 & 1,16 & 0,39 & 0,16 & 0,09 & 0,29 \\
\hline & \multirow{4}{*}{\begin{tabular}{|c|} 
Tak, \\
zastanawiam \\
się nad tym \\
kierunkiem \\
studiów
\end{tabular}} & \begin{tabular}{|c|} 
Odchylenie \\
standardowe
\end{tabular} & 1,717 & 1,912 & 1,169 & 1,577 & 1,516 & 1,756 & 1,035 & 0,268 & 0,431 & 0,576 \\
\hline & & $\mathrm{N}$ & 69 & 69 & 69 & 69 & 69 & 69 & 69 & 69 & 69 & 69 \\
\hline & & Mediana & 5,00 & 4,00 & 0,00 & 2,00 & 0,00 & 1,00 & 0,00 & 0,00 & 0,00 & 0,00 \\
\hline & & Średnia & 3,81 & 2,86 & 0,68 & 1,88 & 1,29 & 1,65 & 0,42 & 0,04 & 0,07 & 0,14 \\
\hline \multicolumn{3}{|c|}{ Wartości osobiste } & $\begin{array}{c}\text { Miłość } \\
\text { przyjaźń }\end{array}$ & $\begin{array}{c}\text { Dobre } \\
\text { zdrowie, } \\
\text { sprawność } \\
\text { fizyczna i } \\
\text { psychiczna }\end{array}$ & \begin{tabular}{|c|} 
Poczucie \\
humoru, \\
dowcip
\end{tabular} & $\begin{array}{c}\text { Inteligencja, } \\
\text { bystrość } \\
\text { umysłu }\end{array}$ & $\begin{array}{l}\text { Wiedza, } \\
\text { mądrość }\end{array}$ & $\begin{array}{c}\text { Radość, } \\
\text { zadowolenie }\end{array}$ & $\begin{array}{c}\text { Odwaga, } \\
\text { stanowczość }\end{array}$ & $\begin{array}{c}\text { Dobroć, } \\
\text { delikatność }\end{array}$ & $\begin{array}{c}\text { Ładny } \\
\text { wygląd } \\
\text { zewnętrzny, } \\
\text { prezencja }\end{array}$ & $\begin{array}{l}\text { Bogactwo, } \\
\text { majątek }\end{array}$ \\
\hline
\end{tabular}

\section{DYSKUSJA}

Narastający problem deficytu zasobów kadr medycznych to jeden $\mathrm{z}$ wielu problemów $\mathrm{z}$ jakimi zmaga się polski system ochrony zdrowia. Poziom wydatków na ochronę zdrowia w Polsce należy do jednych najniższych w Europie zarówno w ujęciu nominalnym, jak i w odniesieniu do wartości PKB. Jeśli wielkość przeznaczanych na ochronę zdrowia środków finansowych nie ulegnie zmianie nie będzie możliwe prawidłowe funkcjonowanie opieki zdrowotnej w naszym kraju [11]. Dane Raportu Naczelnej Rady Pielęgniarek i Położnych ukazują, że wskaźnik zatrudnienia pielęgniarek w Polsce na 1 tysiąc mieszkańców w 2016 wynosił 5,24 i stanowił najniższy wynik w krajach Europy a prognozy na rok 2030 są dramatyczne, ponieważ szacuje się, iż wskaźnik ten w roku 2030 wyniesie zaledwie 3,81 [12]. Struktura wieku pielęgniarek w Polsce wskazuje na narastający problem braku zastępowalności pokoleń w tych grupach zawodowych. Jedną z przyczyn tego niekorzystnego zjawiska jest niewielkie zainteresowania młodzieży kształceniem w zawodzie pielęgniarki [7].

W badaniu własnym chęć podjęcia kształcenia na kierunku pielęgniarstwo zadeklarowały tylko dwie osoby, a nad ewentualnym wyborem kierunku zastanawiało się także niewielu respondentów. Podobne wyniki uzyskano w badaniach W. Mędrzyckiej - Dąbrowskiej i wsp., w których wśród 383 respondentów tylko 10\% dziewcząt i 5\% chłopców rozważało edukację w zawodzie pielęgniarki [13]. W badaniach Franek G. i wsp. wśród 100 licealistów odsetek zainteresowanych zawodem wyniósł 17\%, z tego tylko $9 \%$ badanych zadeklarowało chęć podjęcia nauki w zawodzie [14]. Niskie zainteresowanie studiami pielęgniarskimi wskazano także w badaniach A. Krzos i wsp., w których 6,6\% licealistów chciało w przyszłości studiować pielęgniarstwo [15]. Wyniki M. Pierzak z 2016 wskazały na zainteresowanie zawodem 27 osób z 105 badanych licealistów [16]. Przytoczone wyniki zmuszają do refleksji nad przyczyną tak niskiego zainteresowania kształceniem w zawodzie pielęgniarki. Wyniki badań własnych potwierdziły znaczenie niskiego wynagrodzenia, specyfiki pracy oraz małego uznania dla zawodu w społeczeństwie. Podobne wyniki uzyskali autorzy innych prac analizujących ten problem [13-15].

Współcześnie wysoka ranga i prestiż zawodu postrzegany jest przez młodych ludzi głównie przez pryzmat ekonomiczny czyli atrakcyjność wynagrodzenia za pracę, czynnika, który w wynikach badań własnych, miał istotny wpływ na małe zainteresowanie młodzieży kształceniem w zawodzie pielęgniarki. Ślusarska B i wsp. podkreślają znaczenie poznania wartości osobistych jako fundamentu do kształtowania wartości zawodowych $\mathrm{w}$ pielęgniarstwie [17]. Najbardziej cenione wartości młodzieży w badaniu własnym to miłość i przyjaźń oraz dobre zdrowie, sprawność fizyczna i psychiczna. Natomiast za najistotniejsze symbole szczęścia uznano udane życie rodzinne oraz dobre zdrowie. Warto pokreślić, że wartość „bycie potrzebnym dla innych ludzi” wyżej cenili respondenci, które zastanawiali się nad wyborem zawodu pielęgniarki.

Współczesne pielęgniarstwo stwarza podstawy do kolejnych, pozytywnych zmian w zakresie kompetencji, prestiżu i satysfakcji zawodowej i może być atrakcyjnym zawodem dla młodych ludzi, szczególnie ze względu na jego szlachetną misję, wartości i tradycję. Jednak zdaniem D. Koralewicz i wsp. w dzisiejszych czasach to zdecydowanie za mało, aby zachęcić polską młodzież do podejmowania pracy w tej profesji [18]. 


\section{WNIOSKI}

Zainteresowanie młodzieży kształceniem w zawodem pielęgniarki/pielęgniarza jest bardzo małe. Brak zainteresowania kształceniem w zawodzie pielęgniarki determinuje przede wszystkim poziom wynagrodzenia, postrzeganie specyfiki pracy i prestiżu zawodu.

Konieczne jest podjęcie pilnych działań w zakresie promocji zawodu, które przełożą się na postrzeganie przez młodzież zawodu pielęgniarskiego jako atrakcyjnego.

\section{REFERENCES/PIŚMIENNICTWO}

1. GolinowskaS, KocotE, Sowa A.Zasobykadrdla sektorazdrowotnego. Dotychczasowe tendencje i prognozy. Zdrowie Publiczne i Zarządzanie 2013;11(2):125-147 doi: 10.4467/208426270Z.14.012.1622.

2. Zając P., Szpakowski R., Pielęgniarstwo-zawód deficytowy? Polski Przegląd Nauk o Zdrowiu 2014; 1(38): 64-68.

3. Kozek W. Pielęgniarki na rynku pracy. Zdrowie Publiczne i Zarządzanie 2013;11 (2):180-190 doi:10.4467/208426270z.14.016.1626.

4. Neilson GR, Lauder W. What do high academic achieving school pupils really think about a career in nursing: analysis of the narrative from paradigmatic case interviews. Nurse Educ Today. 2008;28(6):680-90 doi: 10.1016/j.nedt.2008.03.008.

5. Nelson G.R, Jones M.C. What predicts the selection of nursing as a career choice in 5th and 6th year school students? Nurse Educ Today. 2012; 32:588-593. doi: 10.1016/j.nedt.2011.06.011.

6. Glereana N., Hupila M., Talmana K., Haavistob E. Young peoples' perceptions of the nursing profession: An integrative review. Nurse Educ Today. 2017; :57 95-102 doi:org/10.1016/j.nedt.2017.07.008.

7. Strategia na rzecz rozwoju pielęgniarstwa i położnictwa w Polsce, Warszawa 2017, http://www.mz.gov.pl/aktualnosci/zespol-ds-opracowania-strategii-na-rzeczrozwoju-pielegniarstwa-i-poloznictwa-w-polsce-zakonczyl-prace/[dostęp 3.03.2019].

8. Kucharski A, Ligocka M. Aspiracje edukacyjne młodzieży a motywy studiów. Pedagogika Społeczna 2014;1 (51):57- 74

9. Lelińska K. Znaczenie socjologicznych teorii wyboru zawodu w pracy doradcy zawodowego. [W]: Bednarczyk H, Figurski J, Żurek M. (red.), Pedagogika pracy: doradztwo zawodowe. Wyższa Szkoła Pedagogiczna ZNP w Warszawie, Instytut Technologii Eksploatacji w Radomiu, Warszawa 2004, s.114-123.

10. Juczyński Z. Narzędzia pomiaru w promocji i psychologii zdrowia. PTP, Warszawa 2001, s.122-127.

11. State of Health in the EU Polska Profil systemu ochrony zdrowia 2017. https:// ec.europa.eu/health/sites/health/files/state/docs/chp_poland_polish.pdf[dostęp: 30.07.2019].

12. Raport Naczelnej Rady Pielęgniarek I Położnych. Zabezpieczenie społeczeństwa polskiego w świadczenia pielęgniarek i położnych. Warszawa: NIPiP. 2017 https:// nipip.pl/wp-content/uploads/2017/03/Raport_druk_2017.pdf [dostęp: 30.07.2019].

13. Mędrzycka-Dąbrowska W, Bąkowska G, Kwiecień-Jaguś K, Gaworska-Krzemińska A. Postrzeganie zawodu pielęgniarki przez młodzież szkół ponadgimnazjalnych, jako wybór przyszłego zawodu - doniesienia wstępne. Probl Piel. 2012; (20) 2:192-200.

14. Franek $G$, Kulik $H$, Ferdyn M. Zainteresowanie zawodem pielęgniarki wśród młodzieży szkół licealnych. Probl Piel. 2012; 4 (20):423-430.

15. Krzos A, Rząca M, Zaniuk M, Gębka M, Kozioł A, Szmołda I, Sikorska I. Postrzeganie zawodu pielęgniarki przez uczniów szkół gimnazjalnych i ponadgimnazjalnych. [W:] Pielęgniarstwo wczoraj, dziś, jutro ... tom IIW wyd. Państwowa Wyższa Szkoła Zawodowa w Ciechanowie, 2013, s.118-126.

16. Pierzak M.T. Nursing as a profession practiced in the future - opinion of junior high school students. Journal of Education, Health and Sport 2017;7(7):125-140 doi http://dx.doi.org/10.5281/zenodo.824373.

17. Ślusarska B, Barczak S, Zarzycka D, Dobrowolska B, Cuber T. Znaczenie wartości osobistych i symboli szczęścia wśród pielęgniarek aktywnych zawodowo. Probl Piel. 2011;19 (2):219-227.

18. Koralewicz D, Kuriata E.I, Mróz S. Opinia studentów pielęgniarstwa na temat wizerunku zawodowego pielęgniarek w Polsce. Piel Zdr Publ. 2017;4:285-292 doi: 10.17219/pzp/79703.
Manuscript received/Praca zgłoszona do czasopisma: 20.06.2019

Manuscript accepted/Praca zaakceptowana do druku: 02.08.2019

Translation/Tłumaczenie: Lingua Line Language Center

Podziękowanie dla pani Natalii Kotomskiej za pomoc w zebraniu materiatu badawczego.

Acknowledgements to Natalia Kotomska for help in collecting research material. 